Eduard P. Mikheev

head of the Exhibition Department

Stroganov Moscow State Art Industrial Academy

e-mail:abba41@yandex.ru

Moscow, Russia

ORCID 0000-0002-2312-6912

DOI: $10.36340 / 2071-6818-2019-15-3-75-87$

\title{
Colouristic Analysis of Russian Orders
}

Summary: In addition to the symbolism, compositional laconism and colour palette are important for the visual perception of an order. The combination of colours is the first thing perceived by the human eye. This article offers an analysis, based on colour science and colouristics, of the colours and their combinations used to create orders. The work examines three periods of the Russian order: the Russian Empire, the Soviet Union, and modern Russia.

Gold, silver, platinum, and sometimes copper are used in the manufacture of orders. Each of these metals has its own colour: gold is golden yellow, silver and platinum are of silver-grey colour, and copper is golden pink. The colour of the enamel may be ruby red, white, blue, grey, black and green.

All orders are divided into four groups. Orders for which only one colour is used are in the first group. These are orders made of one type of metal without the use of enamel. The second group includes awards to which, in addition to the base metal, enamel or the second metal is added. Orders consisting of three colours are in the third group; orders with four colours or more are in the fourth group.

An order which is made using only ruby red enamel can be considered an example of a good and concise combination. The classic combination of the silver-grey metal with red enamel works very well.

The yellow colour of the metal matches with the red one, creating a bright festive palette. The same as the combination of the saturated and the neutral, the golden yellow goes well with the silver-grey.

In addition to the base metals, such as silver and enamel, gilding is used in other awards. As a rule, red is dominant in such orders; some elements are gilded but the silver-grey colour balances the bright combination of red and golden.

The next category of orders with four or more colours can be divided into two subgroups. The first subgroup includes orders with one or two dominant colours whereas orders with four or more colours, distributed relatively evenly, are in the second one.

Having analysed the orders of the three historical periods of Russia, the following conclusions can be drawn: the royal orders are more conservative, the 
most interesting colour combinations are from the Soviet era, the modern awards have largely lost the experience of previous generations.

Key words: colouristics, colour science, order

Precious metals - silver, gold, and platinum, are traditionally used in the manufacture of orders. Golden yellow and silver-grey are the colours corresponding to these metals. In rare cases, golden yellow or golden pink copper was used in the manufacture of Chapter orders in Tsarist Russia. The ruby red colour was the most frequent enamel colour of orders of Tsarist Russia and the Soviet Union. Red is less common in modern Russian orders. White, blue, grey, black, and green are complementary colours.

For convenience, all orders may be divided into four groups based on the colour:

1. One colour - one metal.

2. Two colours - one metal and one colour of enamel;

- two metals.

3. Three colours - one metal and two colours of enamel;

- two metals and one colour of enamel.

4. Four colours or more - one or two primary colours;

- the colours are evenly distributed.

The first group includes the Soviet silver Order of Kutuzov III class (Fig. 1), the Order of Bogdan Khmelnitsky III class and the modern Russian Order of Courage, in which enamel was not used. In Tsarist Russia, the Polish Order of Virtuti Militari (Order of Military Virtue) existed for some time. The Order of Virtuti Militari V class was made of silver, it was awarded to all soldiers and non-commissioned officers. By status, it was closer to the decoration of St. George's Cross.

Referring to physiologist Ewald Goering, here is how Johannes Itten, the leading colour researcher in art, describes the perception of grey: "Goering proved that eyes and brain require medium grey colour, otherwise, in its absence, they lose their peace" 1 .

An order made using only ruby red enamel can be considered an example of a good and concise combination. The second group includes such awards. The Soviet silver Order of the Red Star (Fig. 2), the Order of Suvorov III class, the Order of Nakhimov II class and the Order of Glory III class are made in this technique. The classic combination of the silver-grey metal with red enamel works very well.

In contrast, the Order of Glory I class (Fig. 3) is made of gold in s shape of a five-pointed star. The surface of the rays of the star is slightly embossed. On the front side in the central part of the star, there is a circle-medallion with a relief featuring the Spasskaya Tower of the Kremlin in the center. A laurel wreath is

1. Itten J. 2000. The Art of Colour, Moscow, p. 22. 


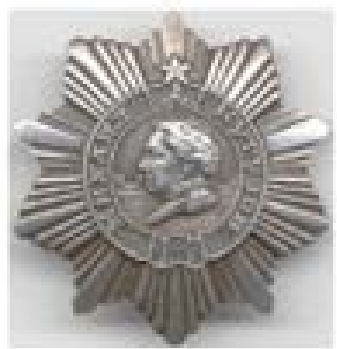

Ill. 1
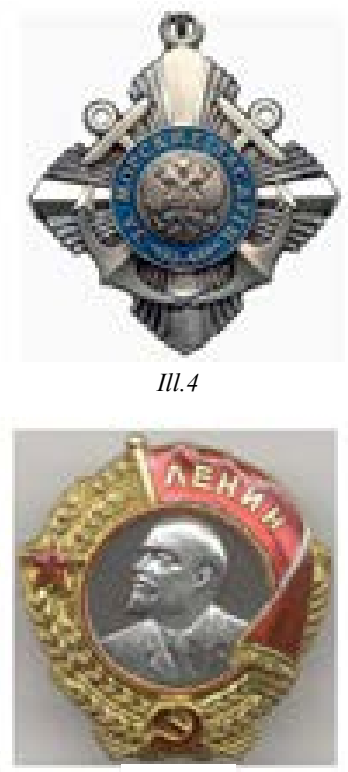

Ill. 7

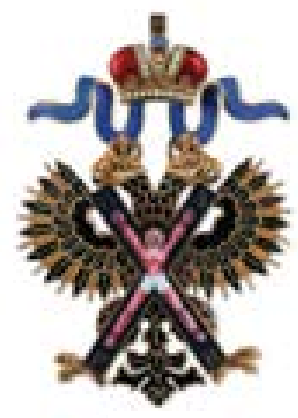

Ill.10

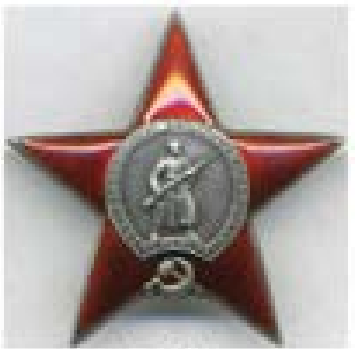

Ill. 2

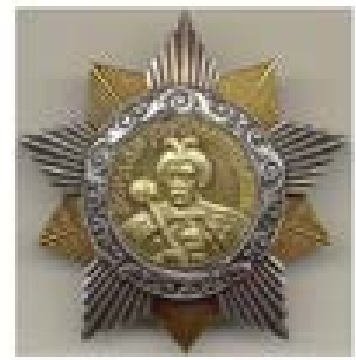

Ill. 5

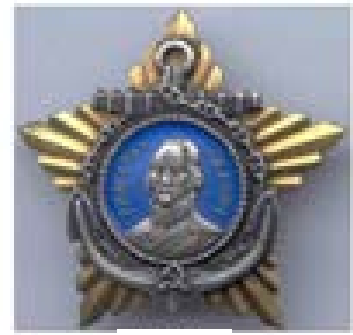

Ill. 8

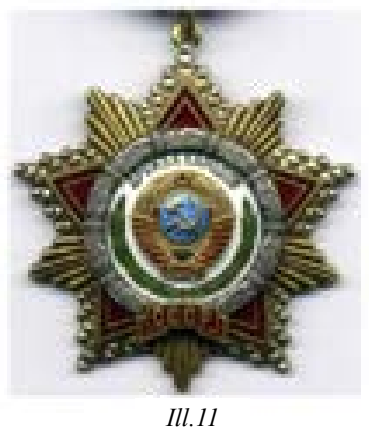

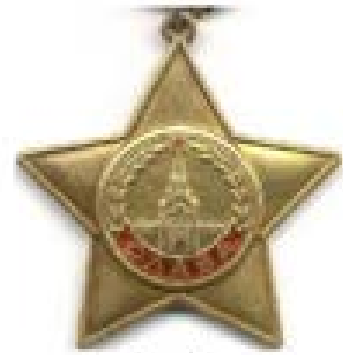

Ill. 3

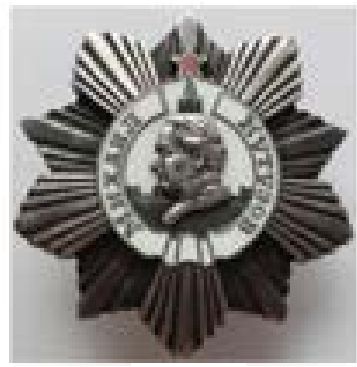

Ill. 6
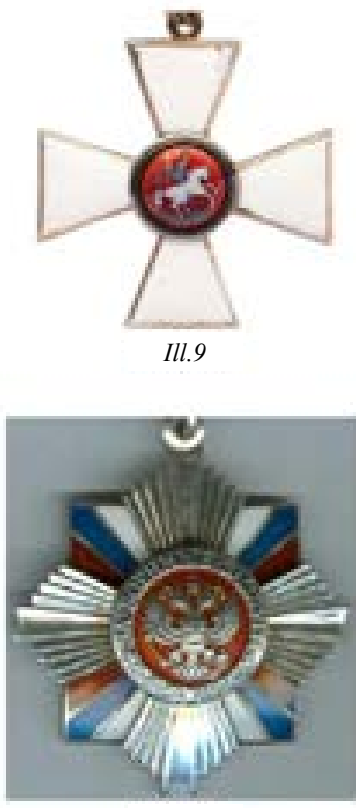

Ill. 12 
along the medal circumference. At the bottom of the circle, a red enamelled scroll bears the relief word "GLORY". The yellow colour of the metal matches with the red one, creating a bright, festive palette. These two tones, as representatives of a pronouncedly warm palette, always attract attention. The gilded modern Russian Order "For Merit to the Fatherland" IV class, in which the cross is rubyenamelled, is another similar example of a two-coloured order.

White enamel was used on the gold royal Order of St. John of Jerusalem abolished in 1810, and blue enamel was used on the modern Russian silver Order "For Naval Merit" (Fig. 4). White enamel on gold on the Order of St. John of Jerusalem is a successful choice, achromatic white colour enhances the solemnity of golden yellow one. Blue and silver combine well on the Order "For Naval Merit"; however, there is still not enough colour accent and tonal contrast.

In the Soviet Order of Bogdan Khmelnitsky I (Fig. 5) and II class, the combination of two colours is due to the use of two metals - gold and silver. The same as a combination of the saturated and the neutral one, the golden yellow goes well with the silver-grey; at the same time, there is a contrast in warmth which enhances expressiveness. The combination is characterized by stylish rigour. In the case of light shades, the pair gains lightness, solar joy wins the battle with the greyness. Together, grey and dark grey shades activate the tonal contrast, which is more catchy, austere, expressive.

Orders in which a combination of three colours is used are in the third group. In addition to the red enamel of the start, there is white enamel on the central circle on the silver Order of Kutuzov II class (Fig. 6). In this case, two achromatic colours and one chromatic are used. In the center of the circle, white enamel emphasizes the silver relief image of Kutuzov, and the ruby-red star of the Kremlin tower organically completes the composition with an accurate accent.

In addition to the base metal and enamel, gilding is used on the next awards. Soviet silver orders were made in such technique: the Order of the Badge of Honour, the Order of the October Revolution, and the Order of Alexander Nevsky. Supplemented by gilded letters and some elements, red is the dominant colour in these orders; the silver-grey colour balances the bright combination of red and gold.

A similar combination of colours is present in the following orders. The Order of Lenin, the highest award of the USSR (Fig. 7), was made of gold and platinum whereas the flag, the star and the "hammer and sickle" emblem were in red enamel. On the Order of Suvorov II class, there is a silver medallion with the red enamelled inscription "Alexander Suvorov" in the center of the gold star. The Order "Mother Heroine" is a golden relief five-pointed star against the background of silver rays diverging in the form of a five-pointed star, the ends of which are located between the ends of the golden star. The badge of the order is suspended by a ring through the suspension loop to a metallic, red-enameled 
mount bearing the relief inscription "Mother Heroine". The inscription and the edges of the mount are gilded.

The Order of Ushakov II class is also made using two metals (Fig. 8). A silver anchor was superimposed on the central gold star, and the circle with the rim was covered with blue enamel. The blue filling of the central medallion highlights the silver image of Ushakov and contrasts with the golden colour of the star.

The next category of orders for which four or more colours are used can be divided into two subgroups. The first subgroup includes orders with one or two dominant colours whereas orders with four or more colours, distributed relatively evenly, are in the second one.

The royal Order of St. George (Fig. 9) and the modern Russian Order of Alexander Nevsky may be included in the first subgroup. The Order of St. George is a white enamelled cross with a red central medallion bearing the image of Saint George on a white horse. The red central medallion is emphasized by the achromatic white enamelled cross. The Order of Alexander Nevsky is in the form of a red enamelled cross with a gold double-headed eagle between each cross arm. In the middle, there is a circular medallion with a narrow relief welt bearing the coloured enameled figure of Prince Alexander Nevsky on horseback. On such awards, the medallions are decorated with black, white, green and blue enamel.

The second subgroup includes royal awards: the Order of St. Andrew the Apostle the First-Called (Fig. 10) and the Order of the White Eagle, the Soviet Order of Friendship of Peoples (Fig. 11), and the modern Order "For Military Merit" (Fig. 12). Black, white, blue and red enamel is used in the royal gold orders. In addition to the colours described above, green enamel is present in the Soviet gilded Order of Friendship of Peoples, and an emphasis is placed on the red-blue-white enamel of the star in the modern silver Order "For Military Merit".

Based on the fact that orders are predominantly small in size and considering that they should attract attention, bright colours look preferable on them. Contrasting combinations are used for the emphasis on details. Having analysed the orders of the three historical periods of Russia, certain conclusions can be drawn: the most interesting colour combinations are from the Soviet era since the royal orders are more concise and conservative, the design of modern awards, unfortunately, in some cases have lost the experience of the past generations in an attempt to combine everything from this experience together.

\section{REFERENCES}

Articles from Scientific Journals

1. Lin, Chiuhsiang, Prasetyo, Yogi, Siswanto, Nio \& Jiang, Bernard. 2019. "Optimization of color design for military camouflage in CIELAB color 
space”, Color research and application, pp. 367-380. DOI: 10.1002/ col.22352 (in English)

Articles from Proceedings and Collections of Research Papers

2. Durov, V.A. 1982. "Iz istorii nagradnykh znakov sovetskikh respublik,,["From the history of the award marks of the Soviet republics "], Aktual "nyye voprosy izucheniya fondovogo muzeya po istorii sovetskogo obshchestva [Actual questions of studying the museum 's fund on the history of Soviet society]. Moscow, pp. 91 - 105. (in Russian)

3. Durov, V. A. 1983. "Iz istorii sovetskikh ordenov" ["From the history of Soviet orders"], Prometey [Prometheus], vol. 13. Moscow, pp. 24 - 32. (in Russian)

4. Khazin A., Gabestro S. 2016. Ordena i medali [Orders and medals], vol. V, Moscow, ISBN 978-5-906930-05-7 (in Russian)

\section{Monographs}

5. Itten, J. 2000. The Art of Colour, Moscow, p. 22. (in English)

6. Kozlov, V.N. 1981. Osnovy dekorirovaniya tekstilya [The Basics of Decorating Textiles], Moscow, p. 133. (in Russian)

7. Kuznetsov, A.A. 1985. Ordena i medali Rossii [Orders and medals of Russia], Moscow, pp. 22-26. (in Russian)

8. Levin. S.S. 2003. Rossiyskiye imperatorskiye i tsarskiye ordena v sobranii gosudarstvennogo istoricheskogo muzeya [Russian Imperial and Royal Orders in the State Historical Museum collection], Moscow, pp. 160 (in Russian)

9. Mericka, V. 1976. Faleristik ein buch uber ordenskunde. Chehoslavakiya, p. 478 (in Czech)

10. Spassky, I.G. 1993. Inostrannyye i russkiye ordena do 1917 goda [Foreign and Russian orders until 1917], Saint- Petersburg, p. 196, ISBN 5-83080042-X. (in Russian)

11. Velinbachov, G.V. 2004. Gosudarstvennyye simvoly Rossii. Istoriya i sovremennost'. Katalog vystavki State symbols of Russia. [ History and modernity. Exhibition catalog], Saint- Petersburg, ISBN 5-98170-005-X (in Russian)

\section{Thesis and Thesis Abstracts}

12. Kalashnikova, A.V. 2015. Sovetskiye respublikanskiye ordena v kontekste kul'tury: nauchnoye opisaniye, katalogizatsiya, muzeynaya prezentatsiya [Soviet republican orders in the context of culture: scientific description, cataloging, museum presentation]. PhD Thesis Abstract. Moscow. (In Russian). 


\section{Resources}

13. Orders of the Russian Empire. Available at: https://order.mediashm.ru (accessed: 10.09.2019). (In Russian).

14. Awards of the Russian Federation. Available at: http://www.gosnagrada. ru/index.htm (accessed: 10.09.2019). (In Russian).

15. Awards of Imperial Russia 1702-1918. Available at: http://medalirus.ru/ rus-ordena/ (accessed: 10.09.2019). (In Russian).

16. vwwState awards of the Russian Federation. Available at: http:/www. award.gov.ru/index.html (accessed: 10.09.2019). (In Russian). 


\section{Эдуард Павлович Михеев}

начальник выставочного отдела Московской государственной художественно-промыиленной

академии им. С.Г. Строганова e-mail:_abba41@yandex.ru

Москва, Россия

ORCID 0000-0002-2312-6912

DOI: $10.36340 / 2071-6818-2019-15-3-75-87$

\section{Колористический анализ отечественных наградных орденов}

Аннотачия: Для визуального восприятия ордена, кроме символической нагрузки, важна композиционная лаконичность и цветовое решение. Именно сочетание цветов - первое, что воспринимается человеческим глазом. В данной статье предлагается, опираясь на цветоведение и колористику, проанализировать какие цвета и их сочетания использовали при создании орденов. В работе исследуются три периода отечественного ордена: Российской империи, Советского Союза и современной России.

При изготовлении орденов используют золото, серебро, платину и иногда медь. Каждый из этих металлов обладает своим цветом: золотисто-жёлтое золото, серебристо-серый цвет серебра и платины, и золотисто-розовая медь. Цвет эмали бывает рубиново-красный, белый, синий, серый, чёрный и зелёный.

Все ордена мы делим на четыре группы. К первой отнесём ордена, где используется один цвет, это знаки, изготовленные из одного вида металла без использования эмали. Ко второй - награды, где кроме основного металла добавляется эмаль, либо второй металл. К третьей - состоящие из трёх цветов и к четвёртой, где присутствуют четыре цвета и более.

Примером хорошего и лаконичного сочетания можно считать ордена с использованием только рубиново-красной эмали. Классический дуэт серебристо-серого металла с красным цветом эмали прекрасно сочетается.

Жёлтый цвет металла сочетается с красным, создавая яркую, праздничную гамму. Золотисто-жёлтый сочетается с серебристо-серым цветом, как насыщенный с нейтральным.

На других наградах, кроме основного металла - серебра и эмали, присутствует золочение. Как правило, на таких орденах доминирует красный цвет, а некоторые элементы позолочены, где серебристо-серый цвет уравновешивает яркое сочетание красного и золотистого. 
Следующую категорию орденов, где используются четыре цвета и более, можно разделить на две подгруппы. Первая - это ордена с одним или двумя доминирующими цветами, а вторая - ордена, где присутствуют четыре цвета или более, и они распределены относительно равномерно.

Проанализировав ордена трёх исторических периодов России, можно сделать следующие выводы: царские ордена более консервативны, наиболее интересные цветовые сочетания представлены советским временем, а современные награды во многом утратили опыт предыдущих поколений.

Ключевые слова: колористика, иветоведение, орден.

При изготовлении орденов традиционно используют драгоценные металлы - серебро, золото и платину. Цвета, соответствующие данным металлам - золотисто-жёлтый и серебристо-серый. В редких случаях при изготовлении капитульных орденов в Царской России использовали золотисто-жёлтую или золотисто-розовую медь. Наиболее частым цветом эмали орденов и Царской России и Советского Союза являлся рубиновокрасный цвет. На современных российских орденах красный цвет встречается реже. Дополнительными цветами являются: белый, синий, серый, чёрный и зелёный.

Все ордена можно условно разделить по цвету на четыре группы:

1. Один цвет: - один металл.

2. Два цвета:

- один металл и один цвет эмали;

- два металла.

3. Три цвета:

- один металл и два цвета эмали;

- два металла и один цвет эмали.

4. Четыре цвета и более:

- один или два основных;

- цвета распределены равномерно.

К первой группе отнесём советские серебряные ордена Кутузова 3 степени (рис.1), Богдана Хмельницкого 3 степени и современный российский орден Мужества, где эмаль не использовалась. В Царской России некоторое время существовал польский орден Virtuti Militari (орден Военных Заслуг). Орден Virtuti Militari 5 степени изготавливался из серебра, им награждались все солдаты и унтер-офицеры, а по статусу он был ближе к знаку отличия Георгиевский крест.

Вот как, ссылаясь на физиолога Эвальда Геринга, описывает восприятие серого цвета крупнейший исследователь цвета в искусстве Иоханес Иттен: 
«Геринг доказал, что глазу и мозгу требуется средний серый, иначе, при его отсутствии, они теряют спокойствие» ${ }^{1}$.

Примером хорошего и лаконичного сочетания можно считать ордена с использованием только рубиново-красной эмали. Эти награды мы отнесём ко второй группе. В такой технике выполнены советские серебряные ордена Красной Звезды (рис.2), Суворова 3 степени, Нахимова 2 степени и орден Славы 3 степени. Классический дуэт серебристо-серого металла с красным цветом эмали прекрасно сочетается.

А вот орден Славы 1 степени (рис.3) изготовлен из золота и представляет собой пятиконечную звезду. Поверхность лучей звезды слегка выпуклая. На лицевой стороне в средней части звезды - круг-медальон с рельефным изображением Кремля со Спасской башней в центре. По окружности медальона - лавровый венок. В нижней части круга выпуклая надпись «СЛАВА» на красной эмалевой ленточке. Жёлтый цвет металла сочетается с красным, создавая яркую, праздничную гамму. Эти два тона, как представители выраженно тёплой гаммы, всегда притягивают внимание. Ещё один подобный пример двухцветного ордена, это позолоченный современный российский орден «За заслуги перед Отечеством» 4-х степеней, у которого крест залит красной эмалью.

На упразднённом в 1810 году золотом царском ордене Святого Иоанна Иерусалимского использовалась эмаль белого цвета, а на современном российском серебряном ордене «За морские заслуги» (рис.4) - эмаль синего цвета. Белая эмаль на золоте ордена Святого Иоанна Иерусалимского удачный вариант, где ахроматический белый цвет усиливает торжественность золотисто-жёлтого. А вот на ордене «За морские заслуги» синий цвет с серебром неплохо сочетаются, но некоторого цветового акцента и тонального контраста всё-таки не хватает.

На советских орденах Богдана Хмельницкого 1 (рис.5) и 2 степени сочетание двух цветов обусловлено использованием двух металлов - золота и серебра. Золотисто-жёлтый сочетается с серебристо-серым цветом, как насыщенный с нейтральным, при этом действует тепловой контраст, который усиливает выразительность. Комбинация отличается стильной строгостью. В случае со светлыми оттенками - пара обретает лёгкость, солнечная радость побеждает в схватке с серостью. Серые и тёмно-серые оттенки активизируют в комбинации световой контраст, который более броский, строгий, выразительный.

К третьей группе отнесём ордена, где используется сочетание трёх цветов. На серебряном ордене Кутузова 2 степени (рис.6) кроме красной эмали звёздочки, присутствует белая эмаль на центральном круге. В данном

1. Иттен И. Искусство цвета. - М., 2000. - С.22. 
случае используется два ахроматических цвета и один хроматический. В центре круга серебряное рельефное изображение Кутузова подчёркивает белая эмаль, а рубиново-красная звёздочка кремлёвской башни органично завершает композицию точным акцентом.

А вот на следующих наградах, кроме основного металла и эмали, присутствует золочение. В подобной технике выполнены советские серебряные ордена: «Знак Почёта», Октябрьской Революции и Александра Невского. На этих орденах доминирует красный цвет и как дополнение - буквы и некоторые элементы позолочены, а серебристо-серый цвет уравновешивает яркое сочетание красного и золотистого.

Подобное сочетание цветов присутствует и на следующих орденах. Высший орден СССР - орден Ленина (рис.7) изготавливался из золота и платины серебристого оттенка, а знамя, звезда, серп и молот покрывались красной эмалью. На ордене Суворова 2 степени - в центре золотой звезды расположен серебряный медальон с надписью: «Александр Суворов», заполненный красной эмалью. А вот орден «Мать-героиня» представляет собой золотую выпуклую пятиконечную звезду на фоне серебряных лучей, расходящихся в виде пятиконечной звезды, концы которой размещены между концами золотой звезды. Знак ордена соединён при помощи ушка и звена с фигурной металлической пластиной, покрытой красной эмалью. На пластинке выпуклая надпись «Мать-героиня». Края пластинки и надпись позолочены.

С использованием двух металлов выполнен и орден Ушакова 2 степени (рис.8), где на центральную золотую звезду накладывался серебряный якорь, а круг с ободком покрывался голубой эмалью. Голубая заливка центрального медальона выделяет серебристое изображение Ушакова и контрастно сочетается с золотым цветом звезды.

Следующую категорию орденов, где используются четыре цвета и более, можно разделить на две подгруппы. Первая - это ордена с одним или двумя доминирующими цветами, а вторая - ордена, где присутствуют четыре цвета или более, и они распределены относительно равномерно.

К первой подгруппе можно отнести царский орден Святого Великомученика и Победоносца Георгия (рис.9) и современный российский орден Александра Невского. Орден Святого Георгия представляет собой крест, заполненный белой эмалью, в центре которого расположен красный эмалевый медальон с изображением Святого Георгия на белом коне. Красный центральный медальон усиливается ахроматической белой эмалью креста. Орден Александра Невского имеет форму залитого красной эмалью креста, между концами которого помещены золотистые изображения двуглавого орла, а в центре - круглый медальон с узким выпуклым рантом. В поле медальона - выполненная цветными эмалями конная фигура князя Александра Невского. 
На подобных знаках медальоны расписываются эмалями чёрного, белого, зелёного и синего цвета.

Ко второй подгруппе отнесём царские награды: орден Святого ап. Андрея Первозванного (рис.10) и орден Белого Орла, советский орден Дружбы народов (рис.11) и современный орден «За военные заслуги» (рис.12). На царских золотых орденах присутствует чёрная, белая, синяя и красная эмаль. На советском позолоченном ордене Дружбы народов кроме описанных выше цветов присутствует эмаль зелёного цвета, а на современном серебряном ордене «За военные заслуги» сделан хороший акцент на красно-сине-белую эмаль штраловой звезды.

Исходя из того, что ордена преимущественно имеют небольшой размер, но при этом они должны привлекать внимание, предпочтительнее в них выглядят яркие цвета, а для акцента деталей их контрастные сочетания. Проанализировав ордена трёх исторических периодов России, можно сделать определенные выводы: наиболее интересные цветовые сочетания представлены советским временем, так как царские ордена более лаконичны и консервативны, а решения современных наград, в попытке объединить опыт предыдущих поколений, к сожалению, в некоторых случаях утрачивают этот опыт.

\section{БИБЛИОГРАФИЯ:}

1. Lin, Chiuhsiang, Prasetyo, Yogi, Siswanto, Nio \& Jiang, Bernard. 2019. "Optimization of color design for military camouflage in CIELAB color space", Color research and application, pp. 367-380. DOI: 10.1002/ col.22352 (in English)

2. Itten, J. 2000. The Art of Colour, Moscow, p. 22. (in English)

3. Vaclav Mericka. Faleristik ein buch uber ordenskunde. Chehoslavakiya, 1976. 478 p. (in Czech)

4. Велинбахов Г.В. Государственные символы России. История и современность. Каталог выставки. СПб., 2004. ISBN 5-98170-005-X

5. Дуров В.А. Из истории наградных знаков советских республик //Актуальные вопросы изучения фондов музея по истории советского общества. М., 1982. С $91-105$.

6. Дуров В.А. Из истории советских орденов // Прометей. Т 13. М., 1983. С $24-32$.

7. Калашникова Александра Владимировна. Советские республиканские ордена в контексте культуры: научное описание, каталогизация, музейная презентация.: диссертация ... кандидата исторических наук : Специальность 24.00.03/ Калашникова Александра Владимировна; [Место защиты: Федеральное государственное бюджетное образо- 
вательное учреждение высшего образования «Московский государственный институт культуры»].- Москва, 2015.- 231 с

8. Козлов В.Н. Основы художественного оформления текстильных изделий. - М., 1981. - С.133.

9. Кузнецов А. А. Ордена и медали России. - М.: Издательство МГУ, 1985. C. $22-26 .-174 \mathrm{c}$.

10. Левин С.С. Российские императорские и царские ордена в собрании государственного исторического музея. М., 2003. 160 с.

11. Спасский И.Г. Иностранные и русские ордена до 1917 года. - СПб: Дорваль, 1993. - С. 196, с илл.. - ISBN 5-8308-0042-X.

12. Хазин А. , Габестро С. Ордена и медали. Том V. - M.: Symbols Publishing, 2016 ISBN 978-5-906930-05-7

13. Ордена Российской Империи: [сайт]. URL: https://order.mediashm.ru (дата обращения: 11.03.2019).

14. Награды Российской Федерации: [сайт]. URL: http://www.gosnagrada. ru/index.htm (дата обращения: 11.03.2019).

15. Награды Императорской России 1702-1918 гг:: [сайт]. URL: http:// medalirus.ru/rus-ordena/ (дата обращения: 11.03.2019).

16. Государственные награды Российской Федерации: [сайт]. URL: http:// www.award.gov.ru/index.html (дата обращения: 11.03.2019).

17. Ордена и медали CCCP: [сайт]. URL: http://mondvor.narod.ru/ordpage. htm (дата обращения: 11.03.2019). 